\title{
TREATMENT MODALITIES FOR THE MANAGEMENT OF ASCITES IN OVARIAN CANCER PATIENTS
}

\author{
Radomir Živadinović1,2, Dane Krtinić3,4, Biljana Živadinović5,6, Aleksandra Petrić1,2, \\ Aleksandar Živadinovićn , Sonja Pop Trajković-Dinić1, ${ }^{1,}$, Milan Trenkić1,2
}

\begin{abstract}
Ascites involve the presence of a higher amount of free fluid accumulated in the abdominal cavity. Pathophysiology of malignant ascites is multifactorial and represents a combination of two basic pathogenetic mechanisms, increased vascular permeability and obstruction of lymphatic drainage. Ascites is the most common symptom of patients with ovarian cancer reporting to a doctor. The primary therapeutic option in the treatment of ovarian cancer is cytoreductive surgery and platinum therapy. Intraperitoneal chemotherapy aims to increase the concentration of the drug at the target site by avoiding a resorptive toxic effect. Of the surgical methods used in palliative treatment of ascites, the creation of peritoneal shunts should be mentioned. A modern innovative approach in the treatment of ascites involves the use of specific monoclonal antibodies that focus on one of the basic etiological factors of ascites - neoangiogenesis. In treatment, a multidisciplinary approach is needed not only for gynecologists but also for anaesthesiologists, gastroenterologists, surgeons, palliative doctors, and a medical oncologist.
\end{abstract}

Acta Medica Medianae 2018;57(4):91-95.

Key words: ascites, ovarian cancer, chemotherapy, monoclonal antibodies

\footnotetext{
${ }^{1}$ University of Niš, Faculty of Medicine, Department of Obstetrics and Gynecology, Niš, Serbia

${ }^{2}$ Obstetrics and Gynecology Clinic, Clinical Center Niš, Niš, Serbia

${ }^{3}$ University of Niš, Faculty of Medicine, Department of Pharmacology and Toxicology, Niš, Serbia

${ }^{4}$ Oncology Clinic, Clinical Center Niš, Niš, Serbia

${ }^{5}$ University of Nišs, Faculty of Medicine, Department of

Neurology, Niš, Serbia

${ }^{6}$ Neurology Clinic, Clinical Center Niš, Niš, Serbia

'University of Niš, Faculty of Medicine, Niš, Serbia
}

Contact: Dane Krtinić

3 Svetozara Markovića Street, 18000 Niš, Serbia

E-mail: kdane86@gmail.com, dane.krtinic@medfak.ni.ac.rs

\section{Epidemiology and pathophysiology of malignant ascites}

The term 'ascites' is defined as the presence of large volumes of fluid accumulated in the abdominal cavity. Under normal conditions, several liters of peritoneal fluid are produced daily and it is not accumulated, but effectively absorbed. This fluid continuously circulates in a clockwise direction help- ing in the lubrication of intestines for their normal movement. Ascites may be of malignant and nonmalignant etiology. Malignant ascites occurs less frequently and accounts for about $10 \%$ of all cases of ascites (1).

The pathophysiology of malignant ascites is multifactorial and is related to a combination of two basic pathogenic mechanism, increased vascular permeability and obstructed lymphatic drainage.

Vascular endothelial growth factor VEGF is the most important factor that stimulates increased vascular permeability and the formation of new blood vessels, neoangiogenesis, but other cytokines, such as basic fibroblast growth factor (bFGF), angiogenin, transforming growth factors (TGF $a$ and $\beta$ ) and interleukin - 8 play important roles as well. Along with an increase of peritoneal blood vessels in size and number, neoangiogenesis results not only in increased permeability, but also in increased overall surface area for filtration.

The next pathogenic mechanism of malignant ascites is increased hydrostatic pressure difference as a result of minor elevation of portal venous pressure in patients with ovarian cancer ( portal veins compression by tumour mass and metastases ). On the other hand, the oncotic pressure difference is reduced since the albumins that are responsible for osmotic intravascular pressure (allows fluid to leak out from the interstitial space) exit blood vessels or degrade into smaller peptides or amino acids (2). 


\section{Ascites and ovarian cancer prognosis}

Ascites is the most common symptom that prompts cancer patients to visit the doctor's office. In $54 \%$ of patients with peritoneal carcinomatosis, ascites was the first detectable sign of malignancy (3).

Unfortunately, the presence of ascites most commonly reveals an advanced stage of the disease, since ascites are produced in only $7 \%$ of cases in stages I and II of the disease, and in $89 \%$ of cases in stages III and IV. The amount of ascitic fluid is in correlation with the stage of the disease, for stages I and II its presence is $<0.5$ liters, but in more than $66 \%$ of cases with stage III and IV its presence is > 0.5 liters.

More than $2 / 3$ of patients report to their doctors in stages III and IV when ascites is indirectly noticed by increased abdominal size and abdominal distension, dyspnea, weight gain, lower extremity edema, nausea and vomiting, the phenomenon of fluid wave and shifting dullness. Survival rate in advanced stages of the disease (III and IV) is $5-20 \%$ (4).

Malignant ascites is not only a sign or a symptom associated with malignant disease. The presence of ascitic fluid in ovarian cancer has an important, almost key role in further progression of malignant disease. The spread of ovarian cancer and the development of abdominal and peritoneal metastases, as well as peritoneal carcinomatosis, depend on ascitic fluid.

Specific cellular and acellular components of ascites form a tumour-friendly environment that may promote the spread and growth of tumour cells, but they may also inhibit the positive response to chemotherapy in tumour cells, thus directly stimulating tumour chemoresistance $(5,6)$.

Chemoresistance and poor response to chemotherapy, often caused by the presence of ascitic fluid, directly correlates with the survival rate and the recurrence of the disease. In chemoresistant tumours, a five-year survival rate is less than $27 \%$ (7). In this way ascites may indirectly affect a malignant disease prognosis, not only by forming a specific microenvironment for stimulating tumour growth, but also by developing chemoresistance.

\section{Therapeutic approach in ovarian carcinoma patients}

Primary treatment option in treating ovarian cancer is cytoreductive surgery and platinum-based therapy with an expected positive treatment response rate of $70 \%$. However, in 12-18 months many of these women will have ascites and recurrence of the disease refractory to standard platinum treatment.

Successful management of ascites is limited by the fact that the complete pathogenic mechanism is still poorly understood, and on the other hand the advanced stage of the disease limits the successful management of the disease and quality of life.

Standard therapy of ascites mainly includes palliative repeated paracentesis in more than $98 \%$ of cases. Paracentesis is performed by inserting a 14 gauge needle with a 16 - gauge catheter. This method is effective in rapid relief of distressing symptoms, primarily including dyspnea, orthopnea, pain and peritoneal reaction in $78 \%$ of cases (8).

However, this method has its limitations, since the risk of paracentesis rises with more than $5 \mathrm{~L}$ of ascitic fluid removal that may affect plasma volume and renal function. For these reasons, 5\% dextrose infused simultaneously with paracentesis has been widely recommended. Other possible risks and complications of this method also include hypoproteinemia, hypotension, secondary peritonitis, perforation, and pulmonary embolism (9).

In order to prevent possible complications and homeostatic imbalance it is necessary to perform blood tests control, focusing on protein and electrolyte levels, and the catheter needle should not be left in situ for longer than 1 day. In order to reduce the risk of infection, antibiotic therapy is sometimes used during the first week of treatment after paracentesis is performed (10).

Diuretic therapy in the management of the ascites is rarely performed ( $61 \%$ of all ascites) and is less effective than paracentesis (45\%) (11). Unlike benign ascites (liver cirrhosis and congestive heart failure), malignant ascites respond poorly to the therapy including fluid and salt restrictions and diuretics that may cause complications such as a decrease in volume, electrolytic imbalance, and renal dysfunction.

It is reported that good control of ascites is achieved with spironolactone at a dose of $150-400$ $\mathrm{mg}$ in patients who showed sodium retention and elevated plasma renin, without serious problems of electrolyte imbalance (12). Patients with malignant ascites and hepatic metastases benefit most from diuretic therapy. Reduction of the blood volume causes the renin-angiotensin - aldosterone system activation, leading to salt retention. Spironolactone is an antagonist to aldosterone, thus the reabsorption of water and salt is decreased.

Pockros proved in his paper that renin levels were elevated in patients with hepatic metastases, while normal renin levels were confirmed in carcinomatosis without hepatic metastases (13). Patients without hepatic metastases and with diuretic use had $1 \mathrm{~kg} / \mathrm{d}$ in weight loss without hypotension, and those without metastases and in carcinomatosis group had $0.5 \mathrm{~kg} / \mathrm{d}$ in weight loss with hypotension and renal dysfunction.

Apart from aforementioned Spironolactone used at a dose of $100-200 \mathrm{mg}$ daily, Furosemide at initial dose of $40-80 \mathrm{mg}$ daily is also used in the management of ascites (14). Due to already mentioned numerous harmful effects, the usage of these drugs is allowed, but for a limited period of time only. Contraindications are hyponatremia $<125 \mathrm{mmol} / \mathrm{l}$, hepato-renal related decrease of sodium excretion to $<30 \mathrm{mmol} /$ day, renal insufficiency with serum creatinine $>1.5 \mathrm{mg} / \mathrm{dl}$, acute encephalopathy and acute bacterial infection (15). The use of diuretics also increases the risk of thromboembolic complications due to chemotherapy drug concentrations, and pos- 
sible additional symptoms include gynecomastia, renal tubular acidosis, and hyperkalemia.

Another palliative treatment of ascites in ovarian cancer is the application of chemotherapeutics into the peritoneal cavity. This treatment aims at delivering higher concentrations of drugs to the target site, while avoiding resorption toxic effects. The most common cytostatic drugs used for the intraperitoneal treatment are cisplatin and paclitaxel. Complications of this method include infections and pain. Limiting factors are short-term effects and a maximum of 5 $\mathrm{mm}$ penetration into a tumour deposit with limiting effects to existing adhesions. Other side-effects include ileus, peritonitis, abscess, and necrosis.

The attempts to potentiate the cytotoxicity of cisplatin and paclitaxel in intraperitoneal application have resulted in utilization of hyperthermic medium $\left(40.5-43^{\circ} \mathrm{C}\right)$. This procedure is called hyperthermic intraperitoneal chemotherapy (HIPEC). The results of HIPEC treatment regarding overall survival rate are better in comparison to reduction of ascitic fluid, but without statistically significant difference (12).

Hyperthermia (over 39 degrees) increases local cytotoxic effects by inhibiting replication and repair. The best results are achieved directly after the surgery (complete cytoreduction) since fibrin depositions and adhesion formations are thin at that time. Combined-modality treatment of surgical procedure and intraperitoneal chemotherapy using cisplatin, bleomycin, and mitomycin $\mathrm{C}$ prevents recurrence of ascites in $75 \%$ of patients (14).

Besides intraperitoneal application of cytostatics, other drugs can be used intraperitoneally, such as intraperitoneal tumor necrosis factor (TNF), interferon, and other immunomodulators (15).

TNF is used at a dose of $0.08-0.014 \mathrm{mg} / \mathrm{m}^{2}$ diluted in 5\% human albumin, applied into the abdomen for 24 - 48 hours, and the procedure is repeated on the $8^{\text {th }}$ day (16).

Improvements regarding reduction of ascitic fluid can be seen after three doses, but improvements in mucinous ovarian cancer have not been reported (17).

Intraperitonel interferon a (IFN) 2b application was described in the studies by Sartori et al. (18). Complete response was achieved in $29.3 \%$, a partial response in $36.6 \%$ and no response in $34.1 \%$ of patients.

One of the surgical methods used in palliative treatment of ascites is peritoneovenous shunting. The first data on peritoneovenous shunts date back to 1974. A modified Denver shunt was developed later. The benefits of this method in comparison to paracentesis include reduced need for repeated paracentesis and maintenance of normal serum albumin concentrations. In malignant ascites, reduction and control of ascites by application of this method was achieved in $75 \%$ of shunts (19). Patients selected for shunt placement should undergo cardiac and respiratory evaluations.

By this method, surgical peritoneovenous shunt is formed, connecting the peritoneum to the vena cava. At a specific pressure, a valve opens and leads the fluid into the vein. There are three different forms of shunts named after their authors: the Hyde, Denver and LeVeen shunts.

Faught et al. evaluated some possible complications of this method, such as fever, coagulopathy, infection and tumor embolization (20). Contraindications are portal hypertension, coagulation disorders, elevated bilirubin levels, cardiac or renal failure, hemorrhagic ascites or fluid protein $>4.5 \mathrm{~g} / \mathrm{l}$. Increased probability of disseminating malignant cells by this treatment modality has not been proved in this study. What is important is that the application of this shunt showed better clinical results for ascites in ovarian cancer patients than in gastrointestinal cancer patients, in relation 50 : $15 \%$ respectively. However, the application of shunts is indicated only for patients in whom other treatments have failed and who can derive benefits if their life expectancy is long enough.

Finally, among other surgical therapeutic procedures, radical peritonectomy is worth mentioning. It is an extensive surgical intervention involving complete removal of the peritoneum, combined with intraperitoneal chemotherapy.

A modern, innovative approach in treating malignant ascites includes administration of monoclonal antibody-based therapy, directed at one of the basic etiological factors of ascites - neoangiogenesis. In that respect, the drugs used, such as anti-vascular endothelial vascular factor (VEGF), may have potential tumour-suppressive effects.

Bevacizumab (Avastin ${ }^{\circledR}$; Genentech, Inc., South San Francisco, CA) is a recombinant humanized monoclonal antibody to VEGF composed of human $I_{1 g} G_{1}$ framework regions and antigen-binding complementarity-determining regions from a murine antibody that blocks the binding of human VEGF to its receptors (21).

Bevacizumab is a humanized monoclonal antibody directed against VEGF-A as target therapy (21). After its initial approval by the Food and Drug Administration (FDA) in 2004 for unresectable colorectal cancer, its indication for the treatment of different cancers has been investigated $(22,23)$. Some investigations report benefits of this therapy combined with platinum therapy in patients with ovarian cancer. The AURELIA trial studied bevacizumab in combination with non-platinum chemotherapy and proved its success in platinum-resistant ovarian cancer (24). Later bevacizumab was approved for use only in recurrent, platinum-resistant ovarian cancer, and today it is approved for platinum-sensitive recurrent ovarian cancer (25).

Therapeutic application of Bevacizumab has also demonstrated significant benefits in patients with recurrent disease and accompanying ascites. Most common side effects are neutropenia and thrombocytopenia, rarely gastrointestinal bleeding, thromboembolic events, hypertension and proteinuria.

The studies analyzing quality of life and the recurrence of the disease in patients with ascites treated with repeated paracentesis and monoclonal anti-vascular drugs have shown that palliative treatment of malignant ascites using paracentesis or combined paracentesis and intraperitoneal chemo- 
therapy negatively impacts patients' health-related quality of life (HRQL) and shortens the disease-free interval. Monoclonal antibody treatment results in better quality of life and in a longer disease-free interval. The median puncture free survival with catumaxomab was 46 days compared with 11 days in the paracentesis group (26).

\section{Conclusion}

Management of patients with ascites and ovarian carcinoma is complex, with additional recurre- nces, and it is often directed to palliative procedures that necessitates hospital environment.

The treatment requires a multidisciplinary approach and includes not only a gyneacologist, but also an anesthesiologist, gastroenterologist, surgeon, palliative care doctor, as well as medical oncologist.

In order to improve overall quality of life and survival of these patients, further investigations of new drugs, monoclonal antibodies, and immunomodulators are needed aiming at prolonged periods between relapses.

\section{References}

1. Runyon BA. Care of patients with ascites. N Eng J Med. 1994; 330(5): 337-42. [CrossRef][PubMed]

2. Stanojević Z, Rančić G, Radić S, Potić-Zećević N, Djordjević $B$, Marković $M$ et al. Pathogenesis of malignant ascites in ovarian cancer patients. Archives of Oncology. 2004; 12(2): 115-18. [CrossRef]

3. Garrison RN, Kaelin LD, Galloway RH, Heuser LS. Malignant ascites. Clinical and experimental observations. Ann Surg. 1986; 203(6): 644-51.

[CrossRef][PubMed]

4. Shen-Gunther J, Mannel RS. Ascites as a predictor of ovarian malignancy. Gynecol Oncol. 2002; 87(1): 7783. [CrossRef][PubMed]

5. Wels J, Kaplan RN, Rafii S, Lyden D. Migratory neighbors and distant invaders: Tumor associated niche cells. Genes Dev. 2008; 22(5): 559-74. [CrossRef][PubMed]

6. Bhowmick NA, Neilson EG, Moses HL. Stromal fibroblasts in cancer initiation and progression. Nature. 2004; 432(7015): 332-7. [CrossRef][PubMed]

7. Kipps $E$, Tan D, Kaye S. Meeting the challenge of ascites in ovarian cancer: New avenues for therapy and research. Nat Rev Cancer. 2013; 13: 273-82. [CrossRef][PubMed]

8. Fischer DS. Abdominal paracentesis for malignant ascites. Arch Inter Med. 1979; 139(2): 235.

[CrossRef][PubMed]

9. Stukan M. Drainage of malignant ascites: Patient selection and perspectives. Cancer Management and Research. 2017; 9: 115-30. [CrossRef]

10. Kim S, Kim B, Song YS. Ascites modulates cancer cell behavior, contributing to tumor heterogeneity in ovarian cancer. Cancer Sci. 2016; 107(9): 1173-8. [CrossRef][PubMed]

11. Gamblin V, Da Silva A, Villet S, El Hajbi F. Supportive care for malignant ascites in palliative phase: Place of paracentesis and diuretics. Bull Cancer. 2015; 102 (11): 940- 5. [CrossRef][PubMed]

12. Chung $M$, Kozuch $P$. Treatment of malignant ascites. Curr Treat Options Oncol. 2008; 9(2-3): 215-33. [CrossRef][PubMed]

13. Pockros PJ, Esrason KT, Nguyen C, Duque J, Woods S. Mobilization of malignant ascites with diuretics is dependent on ascitic fluid characteristics. Gastroenterology. 1992; 103(4): 1302-6. [CrossRef][PubMed]
14. Sharma S, Walsh D. Management of symptomatic malignant ascites with diuretics: Two case reports and a review of the literature. J Pain Symptom Manage. 1995; 10(3): 237-42. [CrossRef][PubMed]

15. Hulin-Curtis SL, Uusi-Kerttula $H$, Jones R, Hanna $L$, Chester JD, Parker AL. Evaluation of CD46 re-targeted adenoviral vectors for clinical ovarian cancer intraperitoneal therapy. Cancer Gene Ther. 2016; 23(7): 229-34. [CrossRef][PubMed]

16. Kaufmann M, Schmid H, Raeth U, Grischke EM, Kempeni J, Schlick E et al. Therapy of ascites with tumor necrosis factor in ovarian cancer. Geburtshilfe Frauenheilkd. 1990; 50(9): 678-82. [CrossRef][PubMed]

17. Loggie BW, Perini M, Fleming RA, Russell GB, Geisinger $\mathrm{K}$. Treatment and prevention of malignant ascites associated with disseminated intraperitoneal malignancies by aggressive combined-modality therapy. Am Surg. 1997; 63: 137-43. [PubMed]

18. Sartori S, Nielsen I, Tassinari D, Trevisani L, Abbasciano V, Malacarne P. Evaluation of a standardized protocol of intracavitary recombinant interferon $a-2 b$ in the palliative treatment of malignant peritoneal effusions. A prospective pilot study. Oncology. 2001; 61(3): 192-6. [CrossRef][PubMed]

19. Smith EM, Jayson GC. The current and future management of malignant ascites. Clin Oncol ( $R$ Coll Radiol). 2003; 15(2): 59-72. [PubMed]

20. Faught W, Kirkpatrick JR, Krepart GV, Heywood MS, Lotocki RJ. Peritoneovenous shunt for palliation of gynecologic malignant ascites. J Am Coll Surg. 1995; 180(4): 472-4. [PubMed]

21. Kobold S, Hegewisch-Becker S, Oechsle K, Jordan K, Bokemeyer C, Atanackovic D. Intraperitoneal VEGF inhibition using Bevacizumab: A potential approach for the symptomatic treatment of malignant ascites? Oncologist. 2009; 14(12): 1242-51. [CrossRef][PubMed]

22. Ferrara N, Hillan KJ, Novotny W. Bevacizumab (Avastin), a humanized anti-VEGF monoclonal antibody for cancer therapy. Biochem Biophys Res Commun. 2005; 333(2): 328-35. [CrossRef][PubMed]

23. NC Institute. FDA Approval for Bevacizumab. 2016.

24. Pujade-Lauraine $E$, Hilpert F, Weber B, Reuss A, Poveda A, Kristensen $G$ et al. Bevacizumab combined 
with chemotherapy for platinum-resistant recurrent ovarian cancer: The AURELIA open-label randomized phase III trial. J Clin Oncol. 2014; 32: 1302-8. [CrossRef][PubMed]

25. Jayson GC, Kerbel R, Ellis LM, Harris AL. Antiangiogenic therapy in oncology: Current status and future directions. Lancet. 2016; 388: 518-29.

[CrossRef][PubMed]
26. Wimberger $P$, Gilet $H$, Gonschior AK, Heiss MM, Moehler M, Oskay-Oezcelik G et al. Deterioration in quality of life (QoL) in patients with malignant ascites: results from a phase II/III study comparing paracentesis plus catumaxomab with paracentesis alone. Ann Oncol. 2012; 23(8): 1979-85. [CrossRef][PubMed]

\title{
Revijalni rad
}

\section{TERAPIJSKI MODALITETI U LEČENJU ASCITA KOD KARCINOMA JAJNIKA}

\author{
Radomir Živadinović1,2, Dane Krtinić3,4, Biljana Živadinović5,6, Aleksandra Petrić1,2, \\ Aleksandar Živadinović7, Sonja Pop Trajković-Dinić1, ${ }^{1,2}$ Milan Trenkićc, ${ }^{12}$
}

\author{
${ }^{1}$ Univerzitet u Nišu, Medicinski fakultet, Katedra za ginekologiju i akušerstvo, Niš, Srbija \\ ${ }^{2}$ Klinika za ginekologiju i akušerstvo, Klinički centar Niš, Niš, Srbija \\ ${ }^{3}$ Univerzitet u Nišu, Medicinski fakultet, Katedra za farmakologiju sa toksikologijom, Niš, Srbija \\ ${ }^{4}$ Klinika za onkologiju, Klinički centar Niš, Niš, Srbija \\ ${ }^{5}$ Univerzitet u Nišu, Medicinski fakultet, Katedra za neurologiju, Niš, Srbija \\ ${ }^{6}$ Klinika za neurologiju, Klinički centar Niš, Niš, Srbija \\ 7Univerzitet u Nišu, Medicinski fakultet, Niš, Srbija
}

Kontakt: Dane Krtinić

Ul. Svetozara Markovića br.3, 18000 Niš, Srbija

E-mail: kdane86@gmail.com, dane.krtinic@medfak.ni.ac.rs

Ascites podrazumeva prisustvo veće količine slobodne tečnosti akumulirane u trbušnoj duplji. Patofiziologija malignog ascita je multifaktorijalna i predstavlja kombinaciju dva osnovna patogenetska mehanizma, povećanu vaskularnu propustljivost i opstrukciju limfatične drenaže. Ascites predstavlja najčešći simptom zbog koga se bolesnice sa karcinomom jajnika javljaju lekaru. Primarna terapijska opcija u lečenju ovarijalnog karcinoma je citoreduktivna hirurgija i terapija platinum. Intraperitonelna hemioterapija ima za cilj da se povećana koncetracija leka nađe na ciljnom mestu, uz izbegavanje resorptivnog toksičnog efekta. Od hirurških metoda koje se koriste u palijativnom tretmanu ascita treba spomenuti stvaranje peritovenskih šantova. Savremeni inovativni pristup u lečenju ascita podrazumeva korišćenje specifičnih monoklonskih antitela koja su usmerena na jedan od osnovnih etioloških faktora ascita - neoangiogenezu. U lečenju je neophodan multidisciplinaran pristup ne samo ginekologa, već i anesteziologa, gastroeneterologa, hirurga, palijativnog doktora, kao i medikalnog onkologa.

Acta Medica Medianae 2018;57(4):91-95.

Ključne reči: ascites, karcinom jajnika, hemioterapija, monoklonska antitela 